\title{
Effect of Agaricus brasiliensis and Lentinula edodes Mushrooms on the Infection of Passionflower with Cowpea aphid-borne mosaic virus
}

\author{
Robson Marcelo Di Piero ${ }^{1 *}$, Quelmo Silva de Novaes $^{2}$ and Sérgio Florentino Pascholati ${ }^{3}$ \\ ${ }^{I}$ Departamento de Fitotecnia; Centro de Ciências Agrárias; Universidade Federal de Santa Catarina; 88040-900; \\ Florianópolis - SC-Brasil. ${ }^{2}$ Departamento de Fitotecnia e Zootecnia; Universidade Estadual do Sudoeste da Bahia; \\ 45083-900; Vitória da Conquista - BA - Brasil. ${ }^{3}$ Departamento de Entomologia, Fitopatologia e Zoologia Agrícola; \\ Escola Superior de Agricultura Luiz de Queiroz; Universidade de São Paulo; 13418-90; Piracicaba - SP - Brasil
}

\begin{abstract}
The objective of the present study was to evaluate the protection of passion fruit plants against CABMV by using preparations from Agaricus brasiliensis and Lentinula edodes mushrooms. In experiments carried out in the greenhouse, the fruiting body extracts from some of the isolates of both mushrooms significantly reduced CABMV incidence in passion fruit plants. This protective effect occurred when the plant leaves, pre-treated with extracts, were later inoculated mechanically with the virus. However, the extracts did not protect the plants in experiments involving CABMV transmission by aphid vectors. An inhibitory effect of mushroom extracts on the virus particles was also demonstrated on Chenopodium quinoa, a CABMV local lesion host, by inoculating the plants with a mixture of extracts and virus suspension. Still in $C$. quinoa, the mushroom extracts from some isolates induced systemic resistance against the virus. These results showed that aqueous extracts from A. brasiliensis and L. edodes fruiting bodies had CABMV infectivity inhibitors, but that was not enough to control the viral disease on passion fruit plants at all, considering they were infected through a vector.
\end{abstract}

Key words: Shiitake; virus inhibitors; induced resistance; biological control; fruiting body extracts

\section{INTRODUCTION}

Passion fruit woodiness disease (PWD) is one of the most serious in relation to the yellow passion fruit (Passiflora edulis Sims f. flavicarpa Deneger), affecting the longevity and the productivity of the plants. The damage is greater when the plants are infected early during the growing season (Rezende, 1994). The symptoms involve leaf deformation and mosaic, plant growth reduction, fruit woodiness and deformity. At least, two potyvirus can cause PWD around the world, Cowpea aphid-borne mosaic virus (CABMV), and
Passion fruit woodiness virus (PWV). Their particles are flexuous rods, $690-760 \mathrm{~nm}$ long and 11-16 nm wide, and their genomes are composed of a single molecule of single stranded, positivesense RNA of approximately 10,000 nucleotides (Fauquet et al., 2005). In Brazil, PWV was considered as the etiological agent of PDW for a long time. However, more recent biological, serological and molecular studies from several Brazilian isolates of this potyvirus have provided evidence that, in Brazil, PWD is primarily caused by CABMV (Nascimento et al., 2006).

\footnotetext{
* Author for correspondence: robson@cca.ufsc.br
} 
There are reports of PWD's occurrence in cultivated or wild species of Passiflora and in Phaseolus vulgaris L. (Inoue et al., 1995). CABMV is able to systemically infect other plants such as Arachis hypogaea L., Centrosema pubescens Benth., Crotalaria juncea L., Glycine max (L.) Merril and Nicotiana sp. (Taylor and Greber, 1973; Chang, 1992). In Chenopodium quinoa Willd., the potyvirus simply causes local lesions on inoculated leaves (Rezende, 1994).

In areas with alternative hosts of the virus and a high population of aphid vectors such as Myzus persicae Sulzer and Aphis gossypii Glover, the disease control is very difficult. There are no genetically resistant or tolerant materials to the virus and the chemical control of the vectors is inefficient since CABMV transmission occurs in a non-persistent way. As a semi-perennial culture, established in the field for a few years, the crossprotection of the passion fruit plants could contribute to the reduction of the damages caused by the virus. However, so far, this action has not been effective in Brazil (Novaes and Rezende, 2003).

Thus, other control measures should be found in an attempt to reduce the virus damage. Among them, the induction of resistance deserves particular attention. Entailing only small risks to the environment, there exists the possibility that virus diseases can be controlled by inducing the resistance in the plants themselves without changing the plant genome. For example, proteins isolated from Clerodendrum aculeatum L. (Verma et al., 1996) and C. inerme (L.) Gaertn plants (Praveen et al., 2001), and also from microorganisms such as the plant growthpromoting rhizobacteria, Pseudomonas fluorescens and Serratia marcescens (Raupach et al., 1996), induce systemic resistance against viruses.

The mushrooms Lentinula edodes (Berk.) Pegler (= Lentinus edodes (Berk.) Singer), known as shiitake, and Agaricus brasiliensis Wasser et al. (= A. blazei Murrill ss. Heinem.) are very cultivated in Brazil (Nascimento and Eira, 2007). They produce antiviral substances against viruses that infect animals, such as Human immunodeficiency virus - HIV (Tochikura et al., 1988), and against viruses that infect plants, such as Tobacco mosaic virus - TMV (Hiramatsu et al., 1987). Some of the substances produced by $L$. edodes and $A$. brasiliensis can activate the animal immune system, aiding the host to fight infections (Mizuno, 1995; Tzianabos and Cisneros, 1996; Ohno et al., 2001). However, there are few reports about the ability of these mushrooms to activate plant defense mechanisms. Thus, the objective of this work was to evaluate the protection of passion fruit plants against CABMV by the use of preparations from L. edodes and A. brasiliensis.

\section{MATERIALS AND METHODS}

\section{Agaricus brasiliensis and Lentinula edodes preparations}

To obtain the aqueous extracts of each fungal isolate, the dry powder of fruiting bodies were mixed with distilled water $\left(14 \mathrm{~mL} \mathrm{~g}^{-1}\right)$, and after $24 \mathrm{~h}$ of incubation at $4{ }^{\circ} \mathrm{C}$, the suspension was filtered through a common filter $\left(8 \mathrm{~g} \mathrm{~cm}^{-2}\right)$ and centrifuged at $20,000 \mathrm{~g}$ for $25 \mathrm{~min}$. Then, the supernatant was filtered through Millipore membrane (pore diameter $=0.2 \mu \mathrm{m}$ ) under aseptic conditions. The fruiting body aqueous extracts were stored in a refrigerator at $4{ }^{\circ} \mathrm{C}$ and used at $40 \%(\mathrm{v} / \mathrm{v})$, after dilution with distilled water. Aqueous extracts at $40 \%(\mathrm{v} / \mathrm{v})$ contained $28.5 \mathrm{mg}$ $\mathrm{mL}^{-1}$ fruiting body dry powder. The A. brasiliensis fruiting bodies were obtained from mushrooms grown in a substrate composed of cane pulp, grass, soybean bran and mineral salts. The L. edodes fruiting bodies were produced in Eucaliptus grandis Hill ex Maiden and E. saligna Smith, and used in 1:1 for the preparation of the aqueous extracts.

\section{Plants and pathogen}

The passionflower used in the experiments was represented by a yellow passion fruit material (Passiflora edulis Sims f. flavicarpa Deneger). The seeds were placed in trays containing Plantimax substrate and, when the seedlings were 6 to $8 \mathrm{~cm}$ high, they were transferred to $2 \mathrm{~L}$ aluminum pots filled with soil and tanned manure, in the proportion of $3: 1(\mathrm{v} / \mathrm{v})$. A similar strategy was adopted to obtain Chenopodium quinoa Willd. plants. The experiments were conducted in a greenhouse or in a screen house in Piracicaba, São Paulo, Brazil.

An isolate of CABMV, obtained from passion fruit plants cultivated in Vera Cruz/SP (Brazil), was provided by Prof. Dr. Jorge A. M. Rezende (Plant Pathology Section - ESALQ/USP). The isolate 
was maintained in passion fruit plants, grown in a greenhouse by monthly mechanical transmissions to new plants.

\section{Protection of passion fruit plants by mushroom extracts}

To study the local protection in passion flower, the fruiting body extracts from $A$. brasiliensis (isolates ABL 99/26, ABL 99/28 and ABL 99/29) or $L$. edodes (isolates LE 96/17, LE 96/22, LE JAB-K and LE 95/01) were sprayed on the whole plant (plants with six to seven leaves) using $15 \mathrm{~mL}$ per plant of an extract at $40 \%(\mathrm{v} / \mathrm{v})$. Plants sprayed with distilled water were used as control. The plants were kept in the greenhouse and, five days after the treatments, they were inoculated mechanically in two leaves of the middle part with the CABMV inoculum obtained from a systemically infected plant. Ten plants were inoculated in each treatment.

To evaluate the systemic effect of the mushroom extracts, the whole plant was treated $(15 \mathrm{~mL}$ per plant; extracts at $40 \% \mathrm{v} / \mathrm{v}$ ), except two leaves of the middle part, which were inoculated mechanically with CABMV after 5 days. Sixteen plants were inoculated in each treatment. For these experiments where mechanical inoculations were carried out, the virus inoculum consisted of $1 \mathrm{~g}$ leaves with symptoms, ground in the presence of $40 \mathrm{~mL}$ of phosphate buffer $0.02 \mathrm{M}(\mathrm{pH} 7.0)$. The inoculum was rubbed on leaves previously dusted with carborundum.

The evaluation of the protection was accomplished by the visual observation of plants exhibiting typical virus symptoms (mosaic, leaf deformation and leaf blisters) and by determining the disease's incidence (test plants with symptoms/total) in each treatment 30 and 60 days after the inoculation. When necessary, the indirect DAS-ELISA test was carried out, as described previously (Bertacini et al, 1998; Novaes and Rezende, 2003) to prove that the symptomless plants were not infected by CABMV. The treatments that received mushroom extracts were compared individually with the control by Independence $\chi^{2}$ test $(\mathrm{P}<0.05)$.

In others protection tests, CABMV was transmitted to passion fruit plants using the vector Aphis gossypii. The plants were sprayed with distilled water (control) or with the fruiting body aqueous extract from isolate ABL 99/26 of $A$. brasiliensis $(40 \% \mathrm{v} / \mathrm{v})$, when they had six to seven leaves, by applying $15 \mathrm{~mL}$ of the preparation per plant. After 5 days, the viral transmission took place. Initially, aphids of the species Aphis gossypii, reared on cucumber plants, were carefully removed from the cucumber leaves with the aid of a brush, and deposited inside a plastic box, where they fasted for $30 \mathrm{~min}$. Later, the aphids were placed to feed for $30 \mathrm{~min}$ on a passion fruit leaf infected with CABMV, and then they were transferred to the healthy passion fruit plants, previously treated. Each plant received eight aphids. Two hours later, the plants were sprayed with deltamethrin (Decis), $1 \mathrm{~mL}$ of the commercial product in $3 \mathrm{~L}$ of water to kill the vectors. In a second experiment, similar to the first one, 12 aphids were deposited per plant. The experiments were carried out in a greenhouse in a completely randomized design. The evaluation of the results was accomplished at 15, 30, 45 and 60 days after the CABMV transmission.

\section{Effect of the environment on the protection of passion fruit plants}

Passion flower seedlings were prepared in trays containing Plantimax substrate that were kept in a screen house where the solar radiation was reduced by $70 \%$. After transplanting to the pots containing soil and tanned manure, the seedlings were divided into two groups. One was maintained in the screen house and the other was taken to a greenhouse. The plants in both the groups were sprayed with fruiting body aqueous extracts from isolates $\mathrm{LE} 95 / 01$ or $\mathrm{ABL}$ 99/26 (15 $\mathrm{mL}$ per plant, at $40 \% \mathrm{v} / \mathrm{v})$. In the control treatment, each plant was sprayed with $15 \mathrm{~mL}$ of distilled water. The CABMV inoculum $(1: 40$, w/v) was applied mechanically in one treated leaf per plant, 3 or 6 days after the treatments, when the plants had six to seven fully expanded leaves. Ten plants were inoculated for each treatment, which were arranged in a completely randomized design. During the experiment, the maximum temperature in each place was registered daily. The evaluation of virus incidence was made at 30 and 60 days after the inoculation. The treatments that received mushroom extracts were compared individually with the control by Independence $\chi^{2}$ test $(\mathrm{P}<0.05)$.

\section{Effect of the mushroom extracts on CABMV infectivity}

Two grams of passion fruit leaves infected with 
CABMV were ground in a mortar in the presence of $25 \mathrm{~mL}$ distilled water. The virus suspension was divided into similar aliquots, to which distilled water or aqueous extract of the fruiting body was added. The final dilution of the CABMV suspension was 1:40 (w/v). The extracts from the isolates LE 96/17, LE 96/22, ABL 97/11 and ABL 99/26 were added separately in the suspension in amounts that resulted in final concentrations of 0 , 20 or $40 \%$ of extract (v/v). Chenopodium quinoa plants, a CABMV local lesion host, were inoculated mechanically with the preparations when they were $35-40 \mathrm{~cm}$ in height. Each treatment had at least four replicates, and a replicate was represented by one pot with two plants. Three to four leaves per plant of the middle part were selected for the inoculation. The experiments were carried out in a completely randomized design. The plants were kept under greenhouse conditions throughout the whole experiment, and the evaluation was accomplished 12 days after the inoculation by counting the number of local lesions on each inoculated leaf. Analysis of variance was performed on data and means were compared by Tukey's test $(\mathrm{P}<0.05)$ using the ANOVA procedure.

\section{Systemic protection of $C$. quinoa plants against CABMV}

C. quinoa plants, $35-40 \mathrm{~cm}$ in height, were sprayed with distilled water or with aqueous extract of the fruiting body from the isolates LE 96/17, LE 96/22, LE JAB-K, ABL 99/26, ABL 99/28 or ABL $99 / 29$, using $6 \mathrm{~mL}$ per plant. The treatments were applied to leaves located on the lower and middle parts of the plants. Five days after the treatments, three to four untreated leaves of the upper part were inoculated mechanically with CABMV $(1: 40, w / v)$ to evaluate each extract's systemic effect against the virus in a host of local lesions. Each treatment had at least five replicates, and a replicate was represented by one pot with two plants. The trials were arranged in a completely randomized design. The plants were kept under greenhouse conditions throughout the whole experiment, and the evaluation was accomplished 12 days after the inoculation by counting the number of local lesions on each inoculated leaf. Analysis of variance was performed on data and means were compared by Tukey's test $(\mathrm{P}<0.05)$ using the ANOVA procedure.

\section{RESULTS}

\section{Protection of passion fruit plants by mushroom extracts}

The aqueous extract of the fruiting body from isolates ABL 99/26 and ABL 99/28 of $A$. brasiliensis, used in the concentration of $40 \%$ $(\mathrm{v} / \mathrm{v})$, inhibited CABMV infection in all the previously treated plants, while the isolate $A B L$ 99/29 reduced virus infection by $66 \%$ (Table 1 ). On the other hand, the extracts from isolates LE 96/17, LE 96/22 and LE JAB-K of L. edodes did not exhibit any effect on the viral infectivity of passion fruit plants (Table 1). In a following experiment, the local protection against CABMV by isolate ABL 99/28 was confirmed, with a reduction of $80 \%$ in virus infection for passion fruit plants whose inoculated leaves had been treated previously (Table 2). However, this mushroom isolate did not promote a significant systemic protection. The isolate LE 95/01 of $L$. edodes reduced the viral infectivity (local effect) by almost $50 \%$, but like ABL $99 / 28$, it did not induce systemic resistance in the plants (Table 2).

Systemic protection of the passion fruit plants against CABMV was also not observed when utilizing extracts from other isolates. The aqueous extract of the fruiting body from ABL 99/29 that induced a local protection, and those from isolates LE 96/17, LE JAB-K and ABL 97/11, did not exhibit any systemic effect, independent of the time interval between treatment and inoculation (data not shown). In the experiments of CABMV transmission by vectors, A. gossypi was able to transmit the virus to the passion fruit plants at a rate of $87 \%$, considering the two experiments carried out. The plant treatment with fruiting body extract from ABL 99/26 did not have any effect on the viral transmission in the first experiment (Table 3). In the second one, the mushroom caused a delay in symptom expression, but it was not able to reduce the disease incidence.

\section{Effect of the environment on the local protection of passion fruit plants}

The experiment carried out under two different sets of environmental conditions showed that passion fruit plants kept in a conventional greenhouse, in the middle of the summer, where the average maximum temperature during the experiment reached $42{ }^{\circ} \mathrm{C}$, were protected by the 
fruiting body aqueous extracts from LE 95/01 and ABL $99 / 26$ to $40 \%(\mathrm{v} / \mathrm{v})$ more efficiently in relation to the plants kept in a screen house, where the average of the maximum temperature was around $34{ }^{\circ} \mathrm{C}$. In a conventional greenhouse, the virus infection on the plants treated with some mushroom extract was $25 \%$, against $50 \%$ in the shaded place. There was a significant difference between these two groups of plants, utilizing Independence Test $(\mathrm{P}<0.05)$ in a $\chi^{2}$ distribution (Table 4).

Table 1 - Local effect of fruiting body aqueous extracts (40\% v/v) from different isolates of Lentinula edodes or Agaricus brasiliensis on the infectivity of Cowpea aphid-borne mosaic virus (CABMV) mechanically inoculated on passionflower.

\begin{tabular}{lcc}
\hline Treatments & Incidence (test plants with symptoms/total) & Reduction on virus infection $(\%)$ \\
\hline Distilled water & $9 / 10$ & - \\
LE 96/17 & $10 / 10$ & 0 \\
LE 96/22 & $10 / 10$ & 0 \\
LE JAB-K & $10 / 10$ & 0 \\
ABL 99/26 & $0 / 10$ & $100^{*}$ \\
ABL 99/28 & $0 / 10$ & $100^{*}$ \\
ABL 99/29 & $3 / 10$ & $66^{*}$ \\
\hline
\end{tabular}

*Treatment significantly different from the control (distilled water) by Independence $\chi^{2}$ test $(\mathrm{P}<0.05)$.

The passion fruit plants were inoculated mechanically with the CABMV 5 days after the treatments.

Table 2 - Effect of fruiting body aqueous extracts (40\% v/v) from isolate LE 95/01 of Lentinula edodes and from isolate ABL 99/28 of Agaricus brasiliensis on the infectivity of Cowpea aphid-borne mosaic virus (CABMV) mechanically inoculated on passionflower.

\begin{tabular}{lcc}
\hline Treatments & $\begin{array}{c}\text { Incidence (test plants with } \\
\text { symptoms/total) }\end{array}$ & Reduction on virus infection (\%) \\
\hline Distilled water & $15 / 16$ & - \\
LE 95/01 - local effect ${ }^{\mathrm{a}}$ & $8 / 16$ & $46.6^{*}$ \\
LE 95/01 - systemic effect & $11 / 16$ & 26.6 \\
ABL 99/28 - local effect & $3 / 16$ & $80.0^{*}$ \\
ABL 99/28 - systemic effect & $11 / 16$ & 26.6 \\
\hline
\end{tabular}

${ }^{a}$ Two pretreated leaves were inoculated mechanically with CABMV 5 days after the treatments.

${ }^{\mathrm{b}}$ Two untreated leaves from pretreated plants were inoculated mechanically with the virus.

* Treatment significantly different from the control (distilled water) by Independence $\chi^{2}$ test $(\mathrm{P}<0.05)$.

Table 3 - Aphid transmission of Cowpea aphid-borne mosaic virus to passion fruit plants pretreated with distilled water or fruiting body aqueous extracts (40\%; v/v) from isolate ABL 99/26 of Agaricus brasiliensis.

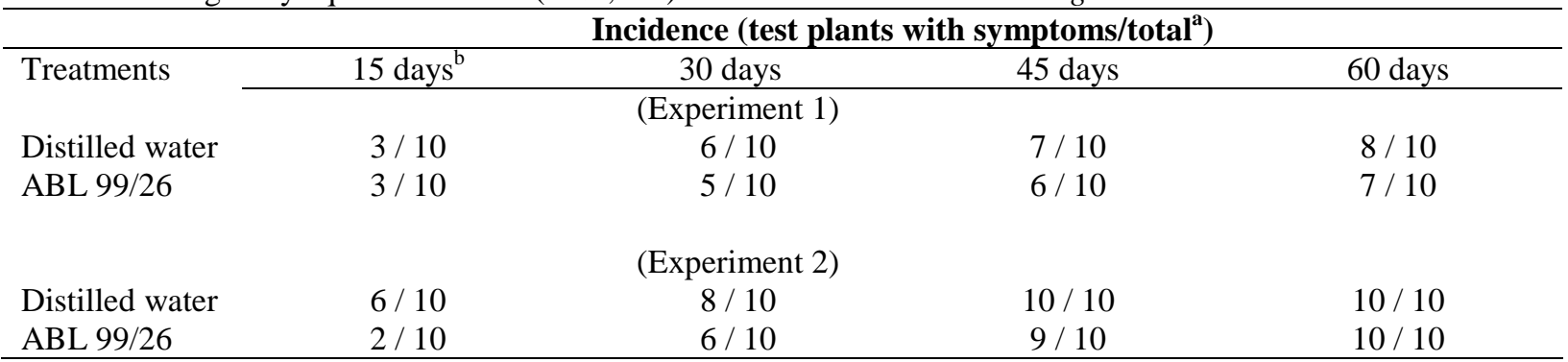

\footnotetext{
${ }^{a}$ Transmission accomplished by the placement of 8 aphids (Aphis gosypii) per plant in the first experiment and 12 aphids per plant in the second one, 5 days after the treatments.

${ }^{\mathrm{b}}$ Time after the aphid transmission.
} 
Table 4 - Effect of the environment on local protection of passion fruit plants against the CABMV, by fruiting body aqueous extracts from the isolates LE 95/01 of Lentinula edodes and ABL 99/ 26 of Agaricus brasiliensis, used at $40 \%(\mathrm{v} / \mathrm{v})$.

\begin{tabular}{|c|c|c|c|c|}
\hline \multirow[b]{2}{*}{ Treatments } & \multicolumn{2}{|c|}{ GREENHOUSE $^{\mathrm{a}}$} & \multicolumn{2}{|c|}{ SCREEN HOUSE $^{b}$} \\
\hline & $\begin{array}{l}\text { Test plants with } \\
\text { symptoms/total }^{\mathrm{c}}\end{array}$ & $\begin{array}{c}\text { Disease Control } \\
(\%)\end{array}$ & $\begin{array}{l}\text { Test plants with } \\
\text { symptoms/total }\end{array}$ & $\begin{array}{c}\text { Disease } \\
\text { Control }(\%)\end{array}$ \\
\hline Distilled water & $10 / 10$ & - & $10 / 10$ & - \\
\hline LE $95 / 01$ - 3 days $^{\mathrm{d}}$ & $2 / 10$ & $80 \% *$ & $3 / 10$ & $70 \% *$ \\
\hline LE 95/01 - 6 days & $3 / 10$ & $70 \% *$ & $6 / 10$ & $40 \%$ \\
\hline ABL 99/26- 3 days & $2 / 10$ & $80 \% *$ & $6 / 10$ & $40 \%$ \\
\hline ABL 99/26- 6 days & $3 / 10$ & $70 \% *$ & $5 / 10$ & $50 \% *$ \\
\hline
\end{tabular}

${ }^{a}$ The average of maximum temperatures in the greenhouse was $41.5^{\circ} \mathrm{C}^{ \pm} 3.1^{\circ} \mathrm{C}$.

${ }^{\mathrm{b}}$ The average of maximum temperatures in the shady place was $34.5^{\circ} \mathrm{C} \pm 1.4^{\circ} \mathrm{C}$.

${ }^{\mathrm{c}}$ One leaf per plant was inoculated mechanically with CABMV.

${ }^{\mathrm{d}}$ Time interval between plant treatment and plant inoculation with CABMV.

* Treatment significantly different from the control (distilled water) by Independence $\chi^{2}$ test $(\mathrm{P}<0.05)$.

Effect of the mushroom extracts on the CABMV infectivity and on the systemic protection of $C$. quinoa

In two independent experiments, it was observed that all the isolates tested (LE 96/17, LE 96/22, ABL 97/11 and ABL 99/26) inhibited CABMV infectivity $(\mathrm{P}<0.05)$, based upon the mean number of local lesions presented on leaves of $C$. quinoa inoculated with the viral suspension mixed with mushroom extracts. The inhibitory effect was more evident when the highest extract concentration was used, except for the isolate LE 96/22 (Fig. 1). In the case of ABL 99/26, the reduction in the CABMV infectivity caused by the aqueous extract of the fruiting body was above $50 \%$. On the other hand, considering the systemic effect of the mushroom extracts against CABMV in C. quinoa, the isolates LE 96/17, LE JAB-K and ABL $99 / 26$ significantly reduced $(\mathrm{P} \leq 0.05)$ the number of local lesions on leaves not directly treated (Fig. 2).

\section{DISCUSSION}

The fruiting body extracts from A. brasiliensis and L. edodes protected passion fruit plants locally against CABMV in mechanical inoculation tests. Considering all the experiments carried out in a greenhouse, the extracts from the isolates $\mathrm{ABL}$ 99/26 and ABL 99/28 of $A$. brasiliensis, used at $40 \%$ (v/v), caused mean reductions of $78 \%$ and
$87 \%$ in virus incidence, respectively, while the isolate LE 95/01 of $L$. edodes reduced it by approximately $60 \%$. But no significant systemic protection of passion fruit plants utilizing any of the mushroom isolates was observed. Thus, the mushrooms probably acted directly on the viral particles, inhibiting CABMV infectivity. In fact, this hypothesis was strengthened when a CABMV local lesion host was used (C. quinoa), allowing the quantification of the antiviral effect from the treatments. All the isolates of L. edodes and A. brasiliensis tested reduced the CABMV infectivity on $C$. quinoa plants significantly.

Many studies have shown the occurrence of viral inhibitors in microorganisms, mainly in studies that involved TMV and tobacco plants. Grohmann and Musumeci (1972) found a TMV infection inhibitor in the culture filtrates from Aspergillus flavus Link. Micolaminaran, a $\beta-1,3$ glucan purified from the Phytophthora megasperma Drechsler cytoplasm, reduced TMV infectivity (Zinnen et al., 1991), and also inhibited the infection of four strains of Cauliflower mosaic virus (CaMV) in Datura stramonium L. and the one of Tomato spotted wilt virus (TSWV) in Nicotiana glutinosa L. (Heinkel et al., 1992). Metabolites produced by the cyanobacteria Synechococcus leopoliensis (Racib) Kom. and Nostoc sp. also acted on TMV particles (Di Piero et al., 2000). For CABMV, there are no reports about the production of inhibitors by microorganisms like L.edodes and A. brasiliensis. 


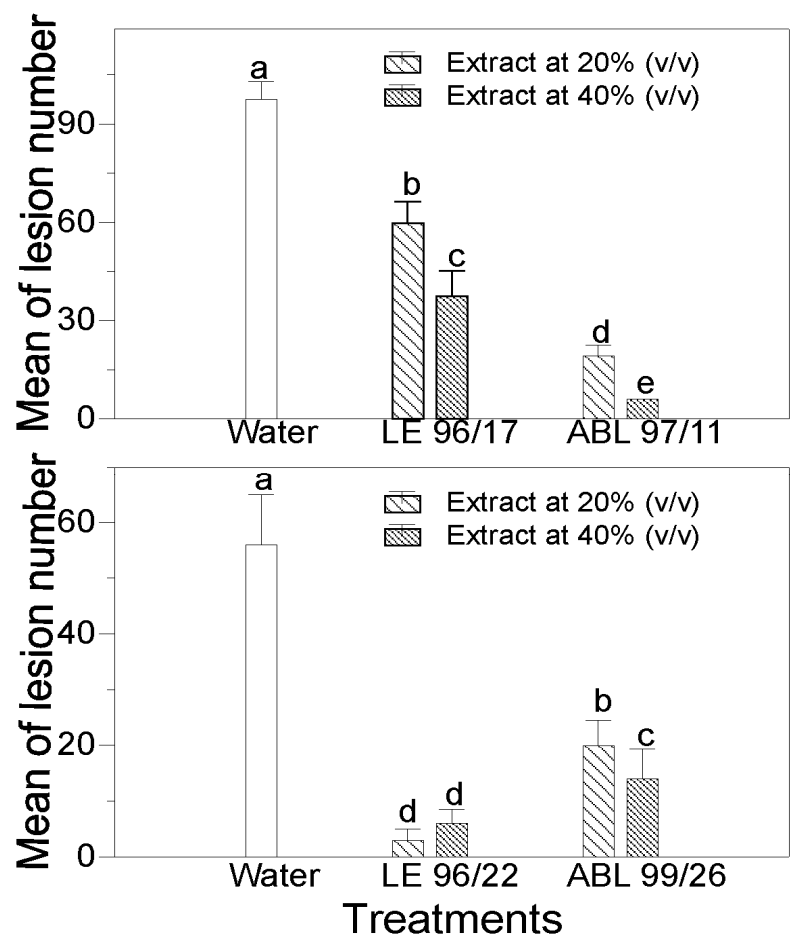

Figure 1 - Effect of fruiting body aqueous extracts from the isolates LE 96/17 and LE 96/22 of Lentinula edodes, and ABL 97/11 and ABL 99/26 of Agaricus brasiliensis on the Cowpea aphid-borne mosaic virus infectivity in Chenopodium quinoa plants, in two independent experiments. The plants were inoculated with a mixture of extracts and virus suspension. Different letters indicate significant differences among the treatments by Tukey's test $(\mathrm{P}<0.05)$.

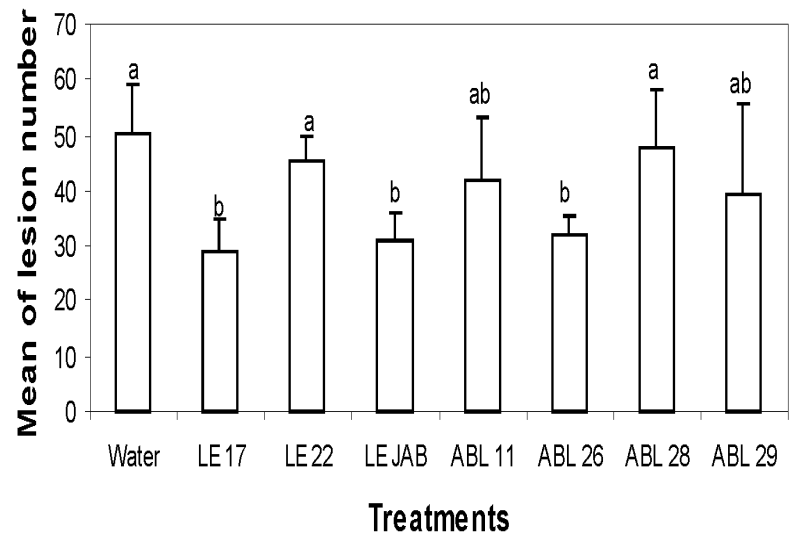

Figure 2 - Systemic effect of fruiting body aqueous extracts from the isolates LE 96/17, LE 96/22 and LE JAB-K of Lentinula edodes, and from ABL 97/11, ABL 99/26, ABL 99/28 and ABL 99/29 of Agaricus brasiliensis, used at $20 \%$ (v/v), on local lesion number caused by the Cowpea aphid-borne mosaic virus in Chenopodium quinoa plants. The plants were sprayed with extracts (lower and middle parts) and inoculated mechanically with CABMV (upper part), 5 days later. Different letters indicate significant differences among the treatments by Tukey's test $(\mathrm{P}<0.05)$. 
Besides the mushroom effect directly on the CABMV particles, some results suggested that the local protection of passion fruit was not the exclusive result of the effect on the virus, but that the fruiting body extracts could be acting, albeit at a lower intensity, on the plant. One such indication was the greater protection of plants kept in the greenhouse in relation to the ones kept in the screen house. It might be expected that, in the shaded place, the residual effect of the extract's application on the plants would be stronger, since factors such as high light intensity and temperature, which could alter the antiviral compounds in the extracts, were not present.

Therefore, if the extract's effect were just on the CABMV particle, the reduction in virus incidence should be higher in the screen house, but this did not take place.

Other studies are necessary to show clearly that the fruiting body extracts would be able to activate defense mechanisms in passion fruit plants. On the other hand, the extracts from some of the mushroom isolates promoted systemic protection against CABMV in C. quinoa, which could be the result of induced resistance. The induction of resistance, in a general way, occurs more frequently in materials that exhibit a certain level of genetic resistance. In this case, $C$. quinoa presented genetic factors that avoided the CABMV systemic movement and was able to respond to the inducers positively.

Results similar to those presented here were obtained by Pennazio and Roggero (1988), who working with Nicotiana tabacum, cv. White Burley, showed that the fourth-leaf inoculation with local lesion viruses, Tobacco necrosis virus (TNV) and Tomato mosaic virus (ToMV), induced systemic resistance against the same viruses when the fifty leaves of the plants were inoculated 5 days later. However, the treatment did not have any effect on a necrotic strain of Potato virus $Y$ $\left(\mathrm{PVY}^{\mathrm{N}}\right)$, on Tobacco mosaic virus (TMV) or on Tobacco rattle virus (TRV), that invade White Burley systemically.

Several studies have shown systemic resistance induction against local lesion viruses, but the treatment's inefficiency against systemic invasion by viruses is of little value to the disease control. The aphid vectors in the field transmit the CABMV in a non-persistent way, through the feeding-probe with their stylets. In that case, to be a valuable alternative for the control of the disease, the extracts would have to exhibit some effect directly on the vector behavior or activate effective defense mechanisms in the plants to avoid the CABMV establishment. These effects were not shown by ABL 99/26 in two independent experiments with passion fruit plants and $A$. gossypi.

Finally, despite the good level of local protection against CABMV due to an antiviral effect and possibly due to a plant activator effect by the mushroom extracts, the practical use of mushrooms in the biological control of PWD needs more work.

\section{ACKNOWLEDGMENTS}

This work was part of the first author's thesis, which was conducted with the financial support of FAPESP, São Paulo, Brazil. We thank Dr. Augusto F. da Eira (UNESP/ Botucatu, São Paulo) for supplying the mushroom fruiting bodies.

\section{RESUMO}

$\mathrm{O}$ endurecimento dos frutos do maracujazeiro, causado pelo Cowpea aphid-borne mosaic virus (CABMV), é um dos problemas mais sérios que atingem a cultura. Tentativas de se obter plantas resistentes ao vírus ou estirpes fracas premunizantes não apresentaram sucesso até $o$ momento. O objetivo do presente estudo foi o de avaliar a proteção das plantas de maracujá contra o CABMV, utilizando preparações dos cogumelos Lentinula edodes e Agaricus blazei, através da indução de resistência. Em experimentos conduzidos no interior de casa de vegetação, os extratos de basidiocarpos de ambos os cogumelos reduziram significativamente a incidência da virose em plantas de maracujá que tiveram as folhas pré-tratadas com esses extratos e que foram posteriormente inoculadas mecanicamente com o CABMV. No entanto, os extratos não protegeram as plantas em experimentos envolvendo a transmissão do CABMV pelo afídeo-vetor. O efeito inibidor dos extratos foi confirmado inoculando-se Chenopodium quinoa com uma mistura de extratos e suspensão viral. Ainda em $C$. quinoa, um hospedeiro de lesão local do CABMV, os extratos de alguns isolados dos cogumelos induziram resistência sistêmica contra o vírus. Os resultados mostram que os extratos aquosos de 
basidiocarpos de L. edodes e A. blazei contêm substâncias inibidoras da infectividade do CABMV, mas isso não é o suficiente para o controle pleno da virose em plantas de maracujá, considerando que elas são infectadas através de um vetor.

\section{REFERENCES}

Bertacini, P.V.; Almeida, A.M.R.; Lima, J.A.A. and Chagas, C.M. (1998), Biological and physicochemical properties of Cowpea severe mosaic comovirus isolated from soybean in the state of Paraná. Brazilian Archives of Biology and Technology, 41, 409-415.

Chang, C.A. (1992), Characterization and comparison of Passionfruit mottle virus, a newly recognized potyvirus, with Passionfruit woodiness virus. Phytopathology, 82, 1358-1363.

Di Piero, R.M.; Pascholati, S.F. and Rezende, J.A.M. (2000), Efeito das cianobactérias Synechococcus leopoliensis e Nostoc sp. na infectividade do vírus do mosaico do fumo (TMV). Summa Phytopathologica 26, 215-220.

Fauquet, C.M.; Mayo, M.A.; Maniloff, J.; Desselberger, U. and Ball, L.A. (2005), Virus taxonomy. Eighth Report of the International Committee on Taxonomy of Viruses. Elsevier Academic Press, San Diego. 1259 p.

Grohmann, A.A. and Musumeci, M. (1972), An inhibitor of tobacco mosaic virus produced by Aspergillus flavus. Arq. Inst. Biol. 39, 69-73.

Heinkel, C.M.; Hudspeth, M.E.S.; Meganathan, R. and Zinnem, T.M. (1992), Further characterization of mycolaminaran-induced resistance: temperature sensivity against Tobacco mosaic virus and function against Cauliflower mosaic virus and Tomato spotted wilt virus. Phytopathology, 82, 637-641.

Hiramatsu, A.; Kobayashi, N. and Osawa N. (1987), Properties of two inhibitors of plant virus infection from fruiting bodies of Lentinus edodes and from leaves of Yucca recurvifolia Salisb. Agric. Biol. Chem. 51, 897-904.

Inoue, A.K.; Mello, R.N.; Nagata, T. and Kitagima, E.W. (1995), Characterization of Passion fruit woodiness virus isolates from Brasília and surrounding region, Brazil. Fitopatologia Brasileira, 20, 479-487.

Mizuno, T. (1995), Bioactive biomolecules of mushrooms-food, function and medicinal effect of mushroom fungi. Food Rev. Int., 11, 7-21.
Nascimento, J.S. and Eira, A.F. (2007), Isolation and mycelial growth of Diehliomyces microsporus: effect of culture medium and incubation temperature. Brazilian Archives of Biology and Technology, 50, 587-595.

Nascimento, A.V.S.; Santana, E.N.; Braz, A.S.K.; Alfenas, P.F.; Pio-Ribeiro, G.; Andrade, G.P.; Carvalho, M.G. and Zerbini, F.M. (2006), Cowpea aphid-borne mosaic virus (CABMV) is widespread in passionfruit in Brazil and causes passionfruit woodiness disease. Arch. Virol., 151, 1797-1809.

Novaes, Q.S. and Rezende, J.A.M. (2003), Selected mild strains of Passion fruit woodiness virus (PWV) fail to protect pre-immunized vines in Brazil. Scientia Agric., 60, 699-708.

Ohno, N.; Furukawa, M.; Miura, N.N.; Adachi, Y.; Motoi, M. and Yadomae, T. (2001), Antitumor bglucan from the cultured fruit body of Agaricus blazei. Biol. Pharm. Bull., 24, 820-828.

Pennazio, S. and Roggero, P. (1988), Systemic acquired resistance induced in tobacco plants by localized virus infection does not operate against challenging viruses that infect systemically. J. Phytopathol., 121, 255-266.

Praveen, S.; Tripathi, S. and Varma, A. (2001), Isolation and characterization of an inducer protein (Crip-31) from Clerodendrum inerme leaves responsible for induction of systemic resistance against viruses. Plant Sci., 161, 453-459.

Raupach, G.S.; Liu, L.; Murphy, J.F.; Tuzun, S.T. and Kloepper, J.W. (1996), Induced systemic resistance in cucumber and tomato against Cucumber mosaic cucumovirus using plant growth-promoting rhizobacteria. Plant Disease, 80, 891-894.

Rezende, J.A.M. (1994), Doenças de vírus e micoplasma do maracujazeiro no Brasil. InMaracujá: produção e mercado. Ed. A.R. São José. UESB, Vitória da Conquista, pp. 116-125.

Taylor, R.H. and Greber, R.S. (1973), Passion fruit woodiness virus. Wallingford: Commonnwealth Mycological Institute and Association of Applied Biologists. 1v. (Description of Plant Viruses, 122).

Tzianabos, A.O. and Cisneros, L. (1996), Prophylaxis with the immunomodulator PGG glucan enhances antibiotic efficacy in rats infected with antibioticresistant bacteria. Ann. NY Acad. Sci., 797, 285-287.

Tochikura, T.S.; Nakashima, H.; Ohashi, Y. and Yamamoto N. (1988), Inhibition of replication and of the cytopathic effect of human immunodeficiency virus by an extract of the culture medium of Lentinus edodes mycelia. Med. Microbiol. Immunol., 177, 235244. 
Verma, H.N.; Srivastava, S. and Kumar, D. (1996), Induction of systemic resistance in plants against viruses by a basic protein from Clerodendrum aculeatum leaves. Phytopathology, 86, 485-492.

Zinnen, T.M.; Heinkel, C.M.; Hudpeth, M.E.S. and Meganathan R. (1991), The role of citoplasmic mycolaminaran in inhibiting initial viral infection of certain Nicotiana species. Phytopathology, 81, 426428.

Received: December 12, 2007; Revised: June 30, 2008; Accepted: July 08, 2009. 